\title{
IMPLEMENTASI PENDIDIKAN KARAKTER DI HOMESCHOOLING KAK SETO YOGYAKARTA
}

\section{THE IMPLEMENTATION OF CHARACTER EDUCATION IN HOMESCHOOLING KAK SETO YOGYAKARTA}

\author{
Ricca Vibriyanthy, Puji Yanti Fauziah \\ Sanggar Kegiatan Belajar, Universitas Negeri Yogyakarta \\ rvyanthy@ymail.com, pujiyantif@gmail.com
}

\begin{abstract}
Abstrak
Penelitian ini bertujuan untuk mengetahui: (1) Implementasi pendidikan karakter, (2) Nilai-nilai karakter yang ditanamkan, (3) Faktor pendukung dan penghambat, dan (4) Hasil dari implementasi pendidikan karakter di HSKS Yogyakarta. Penelitian ini menggunakan pendekatan kualitatif dengan studi kasus. Subjek penelitian adalah kepala sekolah, tutor, orangtua, dan homeschooler kelas 1-3 SD. Pengumpulan data dilakukan melalui wawancara, observasi, dan dokumentasi. Keabsahan data dilakukan melalui pengamatan terus menerus dan trianggulasi. Hasil penelitian mengungkapkan bahwa: (1) Implementasi pendidikan karakter dilakukan secara terpadu pada mata pelajaran, manajemen sekolah, dan ekstrakurikuler (2) Nilai-nilai karakter yang ditanamkan kepada homeschooler mengacu pada finger print scan yaitu tanggung jawab, rasa hormat, keadilan, keberanian, jujur, disiplin, peduli, ketekunan, dan kemandirian. (3) Faktor pendukung yaitu pendekatan secara personal dan faktor penghambat yaitu latar belakang keluarga yang sering memanjakan anak. (4) Hasil dari implementasi pendidikan karakter adalah perubahan sikap dan peningkatan hasil belajar homeschooler.
\end{abstract}

Kata kunci: pendidikan karakter, nilai-nilai, homeschooler.

\begin{abstract}
This study aims to investigate: (1) The implementation of character education, (2) Character values inculcated, (3) Facilitating and inhibiting factors, and (4) The results of the implementation of character education. This study employed the qualitative approach and was a case study. The research subjects comprised the principal, tutors, parents and homeschoolers. The data were collected through interviews, observations, and documentation. The data trustworthiness was conducting continuous observations and triangulation. The result of the study are as follows: (1) Character education is implemented integrated into subject matter learning, school management and extracurricular. (2) The character values inculcated refer the finger print scan, namely responsibility, respect, fairness, courage, honesty, dicipline, caring, perseverance, and independence. (3) The facilitating factor include a personal approach and the inhibiting factos include the background of the families that often spoil the children. (4) The results of the implementation of character education is a changes in the homeschoolers attitudes and the improvement of their learning outcomes.
\end{abstract}

Keywords: character education, values, homeschoolers. 


\section{PENDAHULUAN}

Pendidikan merupakan bagian penting dari kehidupan manusia karena sejak manusia dilahirkan sampai akhir hayatnya tidak bisa terlepas dari proses pendidikan. Masyarakat masih mempunyai pandangan bahwa untuk mendapatkan pendidikan harus dilakukan dengan belajar di sekolah. Dalam Undang-undang No. 20 Tahun 2003 tentang Sisdiknas Pasal 13 ayat (1) dijelaskan bahwa "Jalur pendidikan terdiri atas pendidikan formal, nonformal, dan informal. Oleh karena itu, pemerintah menjamin kebebasan untuk memilih jalur pendidikan yang sesuai dengan kebutuhan dan kemampuan masyarakat.

Sistem persekolahan selama ini lebih menekankan pengembangan kemampuan intelektual untuk mampu mengerjakan soal-soal ujian semata sehingga kurang memberikan perhatian pada pengembangan karakter siswa. Lickona (1993, pp.6-11) menjelaskan dua tujuan utama pendidikan yaitu membantu orang menjadi cerdas dan baik. Oleh karena itu, pendidikan tidaklah cukup hanya menjadikan anak pintar tetapi juga harus membentuk anak dengan karakter baik sehingga memperkuat martabatnya dan menjadikannya bermanfaat bagi orang lain.

Lickona (2004, p.5) menjelaskan bahwa karakter adalah kepemilikan akan "hal-hal yang baik". Dengan demikian, orangtua dan pendidik memiliki tugas penting untuk mengajarkan anak-anak akan karakter yang seharusnya terintegrasi dalam proses pembelajaran. Lickona (1991, p.51) menjelaskan kembali tiga komponen dalam membentuk karakter yang baik, mengetahui hal yang baik, menginginkan hal yang baik, dan melakukan hal yang baik sehingga menjadi kebiasaan dalam berpikir, kebiasaan dalam hati, dan dalam bertindak.

Ki Hajar Dewantara (1977, pp.484485) menjelaskan proses pendidikan perlu melibatkan tripusat pendidikan yang berlangsung dalam sekolah, keluarga, dan masyarakat. Pengajaran budi pekerti untuk anak kecil cukup dengan membiasakan mereka bertingkah laku baik. Sedangkan bagi anak yang sudah dapat berfikir dapat diberikan pengertian seperlunya agar mereka mendapat pengetahuan serta kesadaran akan kebaikan dan keburukan sehingga berperilaku dengan di sengaja. Dengan begitu syarat pendidikan budi pekerti bisa dilakukan dengan metode "ngreti-ngrasanglakoni" (menyadari, menginsyafi, dan melakukan dapat terpenuhi.

Kirschenbaum (1995, pp.31-42) mengelompokkan pendekatan komprehensif pendidikan nilai sebagai berikut: (1) Inkulkasi nilai dan moral (inculcating values and moral); (2) Keteladanan nilai dan moral (modeling values and morality); (3) Fasilitasi nilai dan moral (facilitating values and morality); (4) Pengembangan keterampilan nilai dan moral (skill for value development and moral literacy); (5) Pelaksanaan program pendidikan nilai (implementating a values education program)

Benninga, dkk (2003, pp.19-20) menjelaskan penelitiannya me-ngenai hubungan antara implementasi pendidikan karakter dan prestasi akademik di sekolah-sekolah dasar di California, Amerika Serikat. Hasil penelitian menunjukkan bahwa sekolahsekolah dasar yang melaksanakan pendidikan karakter secara serius dan dirancang dengan baik cenderung memiliki prestasi akademik yang tinggi.

Keterbatasan pendidikan formal saat ini membuat orangtua khawatir untuk menyerahkan sepenuhnya pendidikan anak pada lembaga formal tersebut. Masyarakat mencoba alternatif pendidikan lain yang sesuai dengan kebutuhan anak mereka salah satunya dengan memilih homeschooling.

Kembara (2007, p.27) menjelaskan bahwa homeschooling menjadi konsep alternatif yang layak diterapkan untuk memberi pilihan setiap orang dalam menguasai pengetahuan sesuai dengan gaya mereka masing-masing. Linsenbach (2010, p.1) menjelaskan bahwa orangtua tidak harus menjadi guru profesional ketika ingin menyekolahkan anak-anak di rumah; anak-anak adalah pembelajar alamiah, sementara orangtua adalah guru-guru alamiah.

Saputro (2007, pp.64-65) mejelaskan banyak alasan orangtua memilih homeshooling. Adapun alasan yang melatarbelakangi diantaranya tidak puas dengan pen- 
didikan formal, agar anak punya lebih banyak waktu bersosialisasi, agar anak bisa memperoleh materi akademis yang lebih baik, mampu menjalankan nilai-nilai keagamaan tertentu, anak mempunyai bakat bagus, anak-anak membutuhkan perhatian khusus (autis, hiperaktif, dan lain-lain), anak-anak yang memilih karir, anak-anak yang menderita sakit parah, kendala geografis, fleksibilitas, dan sebagainya.

Undang-Undang No. 20 Tahun 2003 tentang Sisdiknas Pasal 27 ayat 1 disebutkan bahwa "(1) kegiatan pendidikan informal yang dilakukan oleh keluarga dan lingkungan berbentuk kegiatan belajar secara mandiri dan (2) hasil pendidikan informal diakui sama dengan pendidikan formal dan nonformal setelah peserta didik lulus ujian sesuai dengan standar nasional pendidikan." Sementara itu, menurut data yang dihimpun oleh Direktoral Pendidikan Kesetaraan Departemen Pendidikan Nasional, ada sekitar 600 peserta homeschooling di Indonesia. Sebanyak $83,3 \%$ atau sekitar 500 orang mengikuti homeschooling majemuk dan komunitas sedangkan sebanyak $16,7 \%$ atau sekitar 100 orang mengikuti homeschooling tunggal (Mulyadi, 2007, pp.34-36).

Penelitian ini mengambil komunitas homeschooling. HSKS Yogyakarta merupakan kelas jauh HSKS Semarang yang menjadi salah satu bagian dari franchise HSKS yang tersebar di seluruh Indonesia. HSKS Yogyakarta memberikan kesempatan kepada semua anak dengan beragam karakter untuk memperoleh layanan pendidikan yang disesuaikan dengan kebutuhannya. Pendekatan dilakukan secara individu agar setiap anak dapat berkembang secara optimal. Mayoritas homeschooler berasal dari keluarga menengah ke atas sehingga sering dimanjakan. Oleh karena itu, kegiatan yang dilakukan tidak hanya membekali dengan kemampuan intelektual, tetapi lifeskill dan pembentukan karakter menjadi perhatian dalam proses belajar mengajar. Walaupun pelaksanaan pendidikan karakter di HSKS Yogyakarta belum sepenuhnya disadari oleh smua pihak yang terlibat karena berlangsung secara implisit dalam kegiatan seharihari di komunitas.
Homeschooling dengan fleksibilitasnya memungkinkan pendidikan karakter mendapatkan porsi lebih melalui pembelajaran tematik. Penanaman nilai-nilai melalui proses pembelajaran homeschooling bisa lebih optimal dalam pembentukan karakter anak karena adanya keterlibatan lansung orangtua, tutor dan homeschooler yang lebih intensif dibandingkan sekolah formal.

Penelitian maupun pengembangan implementasi pendidikan karakter pada pendidikan formal sudah banyak dilakukan. Namun, pada pendidikan nonformal maupun informal masih sangat terbatas sehingga perlu dilakukan penelitian lebih lanjut untuk melihat bagaimana pelaksanaan implementasi pendidikan karakter pada PNFI.

Berdasarkan permasalahan di atas peneliti tertarik untuk mengadakan penelitian yang difokuskan pada pendidikan karakter di homeschooling. Oleh karena itu, perlu dilakukan penelitian lebih lanjut mengenai "Implementasi Pendidikan Karakter di Homeschooling Kak Seto Yogyakarta.”

\section{METODE}

Penelitian ini menggunakan pendekatan kualitatif dengan jenis penelitian studi kasus (case study). Yin (1989, p.1) menjelaskan studi kasus secara umum merupakan strategi yang lebih cocok bila pokok pertanyaan suatu penelitian berkenaan dengan how atau why, bila peneliti hanya memiliki sedikit peluang untuk mengontrol peristiwa-peristiwa yang akan diselidiki, dan bilamana fokus penelitiannya terletak pada fenomena kontemporer (masa kini) di dalam kehidupan nyata.

Penelitian ini dilakukan di Homeschooling Kak Seto Yogyakarta Jalan Taman Palagan Asri 3, Palagan Tentara Pelajar Km 10 Yogyakarta yang merupakan kelas jauh dari Homeschooling Kak Seto Semarang. Penelitian dilaksanakan pada bulan September 2012 sampai dengan April 2013.

Subjek penelitian adalah 3 orang homeschooler dengan karakteristik sebagai berikut: (1) AG homeschooler kelas 1 SD memiliki ayah berkebangsaan Perancis sehingga perlu menyesuaikan dengan kebudayaan Indonesia baik dalam proses pembelajaran maupun pergaulan; (2) ST homeschooler 
kelas 3 SD memiliki kesulitan dalam calistung sehingga pihak HSKS memprediksi bahwa ST terindikasi disleksia; (3) HD homeschooler kelas 3 SD memiliki kesenjangan antara IQ dan EQ termasuk kategori anak cerdas dengan IQ tinggi namun EQ kurang matang sehingga sangat emosional.

Selain homeschooler yang menjadi subjek penelitian adalah orang dewasa yang turut berpartisipasi dalam kegiatan homeschooling terdiri dari 1 orang kepala sekolah, 3 orang tutor dan 2 orangtua homeschooler. Pengumpulan data menggunakan teknik wawancara, observasi dan dokumentasi. Analisis data menggunakan pengumpulan data, reduksi data, penyajian data dan penarikan kesimpulan. Keabsahan data menggunakan teknik trianggulasi, perpanjangan pengamatan dan meminta pendapat ahli.

\section{HASIL PENELITIAN DAN PEMBAHASAN}

\section{Hasil Penelitian}

HSKS bercermin berdasarkan filosofi sederhana "belajar dapat dilakukan kapan saja, di mana saja dan dengan siapa saja”, dengan mengedepankan kreatifitas, ceria, dan inovatif serta mengutamakan pada character building sebagai investasi saat siswa-siswi terjun di masyarakat. Berdiri secara resmi pada tanggal 4 April 2007 bertempat di Cirendeu, Lebak Bulus Jakarta Selatan. Melihat peluang dan respon positif masyarakat akan kebutuhan homeschooling maka Kak Seto membuka kesempatan untuk kerja sama dalam bentuk waralaba (franchise) kepada masyarakat yang ingin membuka homeschooling di berbagai daerah. Salah satunya yaitu HSKS Semarang yang pada akhir tahun 2010 membuka kelas jauh untuk Yogyakarta (Sumber: Laporan HSKS Yogyakarta Tahun 2011-2012).

Program pembelajaran di kelas semikomunitas HSKS Yogyakarta juga disesuaikan dengan program pembelajaran di HSKS Semarang. Hal tersebut dilakukan untuk menjaga kualitas dan iklim akademik yang dibangun oleh HSKS di bawah naungan Direktur Dr. Nugroho Widiasmadi, M. Eng. Beliau menekankan kepada semua tenaga akademik di HSKS, baik Kelas Semarang dan Yogyakarta untuk tetap menjaga
"Quality Insurance" sebagai upaya penjaminan mutu akademik, yaitu dengan langkah plan, do, monitoring evaluation (monev) and improvement (Sumber: Hasil Wawancara dengan Kepala Sekolah HSKS Yogyakarta).

Siswa siswi yang bergabung di HSKS Yogyakarta berasal dari beragam latar belakang dan karakteristik diantaranya: anak berkebutuhan khusus (hyperactive, autism, dsb); korban kasus bullying di sekolah formal baik fisik maupun psikis, anak yang memiliki kemampuan di bawah rata-rata, normal, dan di atas rata-rata, anak berprestasi/berbakat (artis, atlet, dsb), anak yang tidak cocok dengan peraturan sekolah formal (tidak bisa bangun pagi, berseragam, dsb), dan anak-anak yang tidak diterima atau tidak mendapat kesempatan untuk mengikuti sekolah formal karena berbagai alasan.

Berdasarkan hasil wawancara dengan kepala sekolah, tutor, dan orangtua dapat diperoleh data bahwa implementasi pendidikan karakter di HSKS Yogyakarta sudah berjalan secara implisit. Hal tersebut dapat dilihat dari hasil observasi dan dokumentasi dengan adanya perencanaan akademik berdasarkan visi cerdas berkarakter yang menjadi acuan standar minimal pencapaian tujuan pembelajaran. Pendidikan karakter memang tidak direncanakan secara khusus tetapi terpadu dengan mata pelajaran dan kegiatan sehari-hari di HSKS Yogyakarta.

Proses implementasi pendidikan karakter di HSKS Yogyakarta menggunakan pendekatan secara personal sehingga setiap anak mendapat perhatian untuk dapat berkembang optimal. Tahapan yang dilakukan adalah melihat perkembangan karakter homeschooler terlebih dahulu, jika nilainilai karakter belum muncul sama sekali maka harus dimulai dengan pengenalan nilai, ketedalanan, pembiasaan, dan penguatan.

Tutor memiliki peranan yang penting dalam pembentukan karakter anak tanpa mengabaikan peran orangtua yang lebih besar karena interaksi anak lebih banyak di keluarga. Dalam prosesnya tutor harus benar-benar memahami karakter siswa agar 
dapat memilih metode dan nilai yang tepat untuk ditanamkan pada anak. Selain tutor faktor lain yang sangat menentukan keberhasilan pendidikan karakter adalah pemilihan metode dan cara pendekatan yang tepat kepada anak. Tidak bisa hanya memilih metode tunggal untuk diberlakukan kepada semua anak karena setiap anak unik.

Berdasarkan hasil penelitian memang tidak ada program khusus yang dibuat untuk mengimplementasiktan pendidikan karakter karena homeschooling bersifat fleksibel semua bisa diterapkan baik secara formal, nonformal maupun informal dalam keseharian anak di HSKS Yogyakarta. Implementasi pendidikan karakter selain dilakukan dalam kegiatan sehari-hari dapat juga dapat diberikan pada program pendukung pembelajaran lainnya.

Monitoring dan evaluasi dilakukan dengan koordinasi rutin antara HSKS Yogyakarta dengan HSKS Semarang 3x/bulan. Koordinasi rutin antara tutor dan kepala sekolah dilakukan setiap hari Jum'at. Koordinasi tersebut dinilai cukup efektif karena setiap tutor saling memberikan informasi dan masukan terkait perkembangan masing-masing siswa dan kendala dalam proses pembelajaran.

Minimnya waktu anak berada di homeschooling disadari tidak mudah untuk dapat membentuk karakter anak dalam waktu singkat terlebih lagi karakter anak yang mengikuti homeschooling sangat bervariasi. Walaupun anak memiliki keterbatasan waktu berinteraksi di homeschooling tetapi tidak mengurangi suasana pembentukan moral di HSKS Yogyakarta karena tutor sangat mengetahui kondisi siswa secara mendalam. Walaupun anak memiliki keterbatasan waktu berinteraksi di homeschooling tetapi tidak mengurangi suasana pembentukan moral di HSKS Yogyakarta karena tutor sangat mengetahui kondisi siswa secara mendalam.

Koordinasi untuk memonitor dan mengevaluasi perkembangan anak tidak hanya dilakukan oleh tutor dan kepala sekolah saja tetapi juga turut melibatkan orangtua. Komunikasi selalu dilakukan antara tutor, kepala sekolah dan orangtua dengan memanfaatkan berbagai fasilitas yang ada baik telepon, sms, email dan sebagainya. Selain koordinasi untuk mengevaluasi pendidikan karakter di HSKS Yogyakarta juga dilakukan penilaian tidak hanya dari segi kognitif tetapi juga afektif dan psikomotoriknya. Penilaian ini tidak hanya untuk siswa tetapi juga orangtua untuk menumbuhkan motivasi agar terlibat aktif dalam proses pembelajaran anak.

Pendidikan karakter merupakan proses panjang sebagai sebuah usaha untuk mendidik anak agar memiliki pengetahuan, dapat merasakan dan mempraktekkan nilainilai kebaikan dalam kehidupan sehari-hari, sehingga memberikan dampak positif kepada lingkungan sekitarnya. Walaupun interaksi anak yang minim di homeschooling tutor berusaha secara optimal memanfaatkan waktu dan kesempatan yang ada untuk membantu anak memiliki karakter yang baik.

Keberhasilan suatu program tidak bisa terlepas dari adanya faktor pendukung yang menjadi kekuatan dalam proses pelaksanaannya. Sistem pendidikan yang tepat dan sesuai dengan anak sangat membantu keberhasilan pendidikan karakter. Tidak seperti sekolah formal di homeschooling pendekatan dilakukan kepada masing-masing anak sehingga tutor sangat mengetahui karakter dan kebutuhan siswa.

Komitmen tutor dan kultur homeschooling yang kondusif juga turut mendukung pelaksanaan pendidikan karakter bagi anak-anak. Selain dukungan dari pihak homeschooling peran keluarga terutama orangtua sangat berpengaruh terhadap keberhasilan pendidikan karakter yang dapat berkesinambungan baik di HSKS maupun di rumah.

Banyak hal yang bisa menjadi penghambat dalam pelaksanaan pendidikan karakter di HSKS Yogyakarta. Karakter anak yang beragam dengan latar belakang keluarga yang berbeda-beda juga dapat menjadi penghambat kesinambungan pembentukan karakter anak yang telah diupayakan di HSKS.

Kesibukan orangtua yang sulit meluangkan waktu memberi perhatian kepada anak maupun berkoordinasi dengan pihak homeschooling juga menghambat proses 
implementasi pendidikan karakter. Hal ini menyebabkan tidak bisa bertukar informasi terkait perkembangan anak dan mencari solusi pemecahan masalah jika ada kendala. Oleh karena itu, pihak HSKS terkadang harus melakukan upaya lebih untuk menjalin komunikasi yang tetap berkesinambungan.

Hasil dari implementasi pendidikan karakter memang tidak bisa dilihat secara instan namun untuk jangka panjang karena proses pembentukan karakter memerlukan waktu dan usaha yang sungguh-sungguh. Pelaksanaannya dimulai dengan memberi pemahaman kepada anak sehingga bisa merasakan dan melakukan nilai-nilai kebaikan menjadi perilaku yang diterapkan dalam kehidupan sehari-hari.

Hasil pendidikan karakter dapat dilihat baik dari peningkatan akademik maupun perubahan perilaku. Beragamnya latar belakang anak yang mengikuti homeschooling sehingga tidak memaksakan anak untuk memiliki perubahan yang sama.

Perubahan perilaku dari adanya pendidikan karakter dapat terlihat dan turut dirasakan oleh tutor dalam kegiatan seharihari. Hasil dari adanya pendidikan karakter juga turut dirasakan oleh orangtua murid.

Berdasarkan hasil observasi ketika mengikuti kegiatan outing ke Desa Wisata Kalibuntung dengan membandingkan proses pembelajaran di HSKS Yogyakarta terlihat perubahan perilaku HD yang sudah mampu mengendalikan emosinya, mulai dapat bersosialisasi bersama teman-temannya dan mengurangi kebiasaan buruknya. Begitu pula dengan AG adanya peningkatan kemandirian dan tanggung jawab yang lebih baik ketika pertama kali melakukan observasi pendampingan pembelajaran di HSKS dengan membandingkan proses pembelajaran di rumah melalui tutor visit. Adapun ST berdasarkan pengamatan perubahan sikap maupun kemampuan akademik sudah ada walaupun tidak signifikan karena terkendala oleh proses pendidikan dan informasi yang kurang berkesinambungan dengan orangtua.

\section{Pembahasan}

Perencanaan mutlak diperlukan dalam suatu program untuk menjadi acuan dalam pelaksanaannya. Adapun tahapan perencanaan implementasi pendidikan karakter yaitu: mengenal dan memahami anak seutuhnya sesuai dengan tahap perkembangan dan karakteristiknya; mengidentifikasi jenis-jenis kegiatan; mengembangkan materi pembelajaran untuk setiap jenis kegiatan; dan mengembangkan rancangan pelaksanaan setiap kegiatan di HSKS Yogyakarta.

Perencanaan akademik di HSKS Yogyakarta disesuaikan dengan visi cerdas berkarakter sebagai berikut: (1) SD Kelas 1, 2, dan 3: Pandai menulis, membaca dan berhitung; (2) SD Kelas 4, 5, dan 6: Pengembangan karakter dasar dan kemandirian siswa, menguasai perkalian dan pembagian; (3) SMP: Pengembangan karakter, mental, soft skill, dan kemandirian dengan pembelajaran interaktif dan belajar mandiri; (4) SMA: Pencapaian kelanjutan studi lulusan siswa HSKS ke perguruan tinggi; (5) Ekstrakurikuler, Outing dan Project Class: Mendukung kegiatan belajar mengajar, pengembangan karakter, sikap, mental, bakat, minat dan sportivitas.

Idealnya sebuah perencanaan dibuat secara eksplisit untuk melihat efektivitas pencapaian program pendidikan karakter. Walaupun HSKS Yogyakarta tidak memiliki perencanaan khusus untuk penerapan pendidikan karakter, namun terintegrasi dalam perencanaan akademik. Perencanaan tersebut dilakukan dengan menentukan nilainilai karakter yang ingin ditanamkan, kemudian dituangkan dalam mata pelajaran atau menentukan kegiatan pendukung pembelajaran. Hal ini tidak menghambat upaya HSKS Yogyakarta untuk menciptakan pembentukan karakter homeschooler dalam kegiatan sehari-hari.

HSKS Yogyakarta dengan fleksibilitasnya mampu menggunakan pendekatan formal pada perencanaan akademik yaitu proses pembelajaran yang terjadwal, kegiatan dan kurikulum yang disiapkan dari HSKS Semarang. Walaupun demikian pendekatan nonformal dan informal tetap digunakan 
dalam pelaksanaannya yaitu untuk beberapa anak yang tidak bisa bangun pagi bisa memilih belajar di waktu siang, memilih mata pelajaran dan tutor sesuai keinginannya, metode belajar melalui pendekatan personal dan sesuai dengan kondisi anak.

Hal ini sesuai dengan penjelasan Mulyadi (2007, p.52) sebagai bentuk dari pendidikan informal kunci utama penyelenggaraan homeschooling adalah adanya kelenturan atau fleksibilitas. Perencanaan tidak boleh kaku dan terlalu berstruktur seperti sekolah formal. Jika terlalu disusun dalam kurikulum yang baku maka homeschooling akan kehilangan makna utamanya namun bukan berarti tanpa arahan yang jelas. Fleksibilitas homeschooling tetap dilaksanakan dengan penuh tanggung jawab khususnya orangtua memiliki peranan besar dalam pendidikan anaknya.

Pendidikan karakter di HSKS dilaksanakan sebagai berikut: (1) Pembentukan karakter terpadu dengan pembelajaran pada mata pelajaran yaitu kelas komunitas, distance learning, tutor visit, outing, dan project class; (2) Pembentukan karakter terpadu dengan manajemen sekolah yaitu parents meeting dan budaya akademik; (3) Pembentukan karakter terpadu dengan kegiatan pendukung yaitu olahraga, teater, karawitan, bahasa jawa, agama; (4) Pembentukan karakter terpadu dengan kegiatan ekstrakurikuler yaitu robotik, musik, vokal, modeling, melukis dan menggambar.

Proses pelaksanaan pembelajaran dan kegiatan pendukung lainnya di HSKS Yogyakarta, yaitu sebagai berikut: (1) Siswa program Komunitas, yaitu 60\% tanggung jawab proses pembelajaran orangtua, $40 \%$ tutor HSKS; (2) Siswa program distance learning, yaitu 90\% tanggung jawab proses pembelajaran orangtua, $10 \%$ tutor HSKS; (3) Jadwal komunitas, yaitu seminggu dua kali untuk Kelas 1-5 SD, Kelas 1-2 SMP, dan Kelas 1-2 SMA. Kelas 6, 9, dan 12 belajar setiap hari Senin-Jumat dari pukul 09.00-12.oo WIB; (4) Program ekstrakurikuler, yaitu 1x seminggu, outing dan project class $1 \mathrm{x}$ sebulan, outbound 3 bulan sekali; (5) Parents meeting dan gathering setiap 3 bulan dan 6 bulan sekali.
HSKS menerima siswa dengan berbagai macam latar belakang kondisi seperti anak yang hyperactive, korban bullying, anak yang slower atau IQ di bawah ratarata, anak yang berprestasi baik dengan IQ di atas rata-rata maupun memiliki kegiatan sebagai artis, atlet dan sebagainya sehingga tidak memiliki cukup waktu mengikuti sekolah formal. Oleh karena itu, dalam pelaksanaan pendidikan karakter dibutuhkan pemilihan metode dan pendekatan yang tepat sesuai dengan kebutuhan dan perkembangan anak sehingga tercipta suasana belajar yang menyenangkan dan mampu melibatkan anak secara aktif.

Proses pembelajaran berjalan dengan sangat fleksibel menggunakan pendekatan formal, nonformal dan informal. Berbagai kegiatan yang dilakukan dan biaya yang ditawarkan menunjukkan bahwa tidak selamanya pendidikan nonformal informal identik dengan "murahan dan dilaksanakan sekedarnya" tetapi mampu menjadi pilihan masyarakat dalam memenuhi layanan pendidikan yang berkualitas sesuai dengan karakter anak yang unik.

Zuchdi, dkk (2012, pp.35-41) menjelaskan evaluasi komprehensif dilakukan untuk mengetahui ketercapaian tujuan. Secara lengkap, tujuan pendidikan karakter harus meliputi tiga kawasan yaitu yang meliputi tiga kawasan yakni pemikiran, perasaan, dan perilaku.

Monitoring dan evaluasi pendidikan karakter dilaksanakan mengacu pada "Quality Insurance" (Penjaminan Mutu Akademik) dengan konsep Plan, Do, Monev, dan Improvement. Koordinasi antara tutor dan kepala sekolah juga rutin dilakukan setiap hari Jumat. Evaluasi ini dilakukan untuk mendiskusikan permasalahan anak secara personal sehingga menghasilkan solusi yang dapat dilakukan segera untuk melihat perkembangannya. Penanganan secara personal dengan melihat case by case lebih efektif karena setiap siswa mendapatkan perhatian dan solusi sesuai dengan kebutuhan masing-masing.

Koordinasi dengan melibatkan orangtua juga dilakukan dengan memberikan informasi terkait perkembangan anak sehari-hari di HSKS Yogyakarta. Komunikasi 
tersebut terjadi secara dua arah baik dengan memanfaatkan berbagai media yang ada baik melalui telepon, sms, email, dan sebagainya. Tutor dan orangtua juga memanfaatkan waktu ketika mengantar atau menjemput anak untuk saling berbagi informasi tentang perkembangan anaknya. Secara formal pertemuan rutin dilakukan setiap tengah semester, semesteran dan akhir tahun dalam agenda parents meeting.

Penilaian juga dilakukan tidak hanya aspek kognitif tetapi juga aspek afektif dan psikomotorik anak. Dalam laporan hasil belajar ada penilaian terkait sikap homeschooler seperti kedisiplinan, tanggung jawab, kerapihan, dan sebagainya. Keaktifan anak dalam mengikuti kegiatan ekstrakurikuler turut menunjang penilaian. Tidak hanya keaktifan anak tetapi keaktifan orangtua terlibat dalam pembelajaran anak men-jadi aspek penilaian lain. Hal ini sangat berbeda dengan sekolah formal yang cenderung menilai anak saja dari segi kognitif dan mengabaikan peranan orangtua dalam proses pembelajaran.

Penilaian tersebut dituangkan dalam laporan perkembangan anak yang dibuat oleh wali kelas berdasarkan tutor yang mengampu. Monitoring dan evaluasi juga dilengkapi dengan berbagai instrumen seperti student kit, parent kit, portofolio dan parenting berdasarkan hasil pengamatan kegiatan sehari-hari homeschooler.

Megawangi (2009, p.93) menjelaskan nilai-nilai karakter yang perlu ditanamkan kepada anak-anak adalah nilai-nilai universal di mana seluruh agama, tradisi, dan budaya menjunjung tinggi nilai-nilai tersebut. Nilai-nilai yang ditanamkan kepada homeschooler di HSKS Yogyakarta mengacu kepada hasil finger print scan yaitu tanggung jawab, rasa hormat, keadilan, keberanian, jujur, disiplin, peduli, ketekunan, dan kemandirian.

Dalam keseharian HSKS memberikan suasana lingkungan sekolah yang sesuai dengan nilai-nilai moral walaupun tidak memiliki program pendidikan karakter secara tertulis dan kadang penerapan nilai terjadi tanpa disadari maupun terintegrasi dalam mata pelajaran disebut hidden curriculum (kurikulum tersembunyi). Melalui interaksi sehari-hari dengan pemberian contoh dilakukan oleh tutor dan akhirnya melakukan pembiasaan melalui nasihat, diskusi, tanya jawab serta refleksi kegiatan.

Finger print scan membantu tutor sebagai panduan awal mengenal karakter homeschooler untuk selanjutnya dikembangkan. Selain itu penentuan nilai yang akan ditanamkan disesuaikan dengan kondisi anak. Seperti HD yang sudah memiliki IQ di atas rata-rata namun memiliki kesenjangan dengan emosionalnya maka tutor akan melatih kematangan emosinya agar bisa bersosialisasi dengan anak lainnya. ST yang kurang memiliki kemandirian dan tanggung jawab maka tutor akan membiasakan nilai-nilai tersebut selama proses pembelajaran. AG yang sudah terbiasa mandiri namun karena biasa tinggal di luar negeri sehingga perlu diajarkan nilai-nilai terkait norma di Indonesia.

Penanaman nilai di HSKS tidak terpaku pada kebakuan nilai apa saja yang akan diterapkan tetapi disesuaikan dengan kondisi anak. Nilai mana yang sudah dimiliki anak dengan baik akan dilatih untuk menjadi suatu pilihan nilai yang akan dijadikan pedoman dalam perilaku. Kemudian nilai mana yang belum dapat berkembang dengan baik atau belum dimiliki maka akan diberikan pengenalan nilai secara kognitif, penghayatan nilai secara afektif dan akhirnya pengamalan nilai secara nyata oleh homeschooler dalam kehidupan sehari-hari. Untuk proses ini diperlukan adanya kerja sama yang baik antara pihak homeschooling, orangtua, dan masyarakat untuk menjaga kesinambungan karakter baik yang sudah dimiliki anak.

Ada banyak faktor yang mendukung keberhasilan implementasi pendidikan karakter di HSKS Yogyakarta antara lain: (1) Badan tutorial yang memiliki komitmen; (2) Budaya akademik yang kondusif untuk pembentukan karakter anak; (3) Sistem mengajar dan pemecahan masalah yang fokus secara personal; (4) Regulasi dan aturan dalam proses pembelajaran; (5) Kelengkapan instrumen penilaian untuk memantau perkembangan siswa; dan (6) Kerja sama antara tutor dan orangtua yang baik 
dalam mengkondisikan anak untuk terjadi pembelajaran yang berkesinambungan.

Keberhasilan suatu program juga tidak terlepas dari adanya hambatan dalam pelaksanaan pendidikan karakter di HSKS Yogyakarta. Adapun beberapa faktor penghambat antara lain: (1) Latar belakang keluarga yang sebagian besar kelas menengah sehingga sering memanjakan anak; (2) Kesibukan orangtua sehingga minim untuk berkoordinasi dengan pihak HSKS dan memberikan perhatian pada pendidikan anak; (3) Minimnya sarana dan prasarana yang ada karena harus melakukan pengajuan terlebih dahulu ke HSKS Semarang; (4) Waktu interaksi anak minim sehingga sangat terbatas melakukan penanaman nilai-nilai yang dapat berkesinambungan baik di lingkungan keluarga maupun masyarakat; dan (5) Kemampuan memfilter diri sendiri dari pergaulan lintas vertikal dan pemanfaatan IPTEK yang kurang tepat.

Hasil dari implementasi pendidikan karakter tidak bisa dilihat secara instan karena pendidikan karakter sebagai proses panjang yang nantinya akan membentuk perilaku anak dalam kehidupan sehari-hari. HSKS Yogyakarta memiliki siswa yang lebih bervariasi dibandingkan sekolah formal. Oleh karena itu, diperlukan usaha lebih keras untuk dapat menanamkan nilai-nilai sehingga terbentuk karakter anak yang baik.

Tutor di HSKS Yogyakarta sangat mengetahui karakter masing-masing anak dan juga kondisi anak ketika di rumah. Hal ini membantu tutor untuk dapat menerapkan metode dan memlilih pendekatan yang sesuai kondisi anak dalam proses pembelajaran. Hasil finger print scan juga turut membantu tutor sebagai bahan rujukan dalam mengembangakan karakter anak. Untuk selanjutnya hasil pendidikan karakter ini dapat dilihat dari perubahan perilaku anak dan kemampuan akademiknya.

HD yang termasuk kategori anak cerdas namun memiliki kesenjangan antara IQ dan EQ. Untuk kondisi anak seperti ini pihak HSKS lebih menekankan pada perubahan perilaku yang lebih baik dengan melatih kematangan emosinya. Awalnya HD belum bisa untuk belajar di komunitas dan tidak semua orang bisa menangani proses pembelajarannya. Bahkan ketika outing HD sempat mengamuk dalam bus sehingga supir dan kernet tidak mau jalan sebelum HD diturunkan. Dengan penuh kesabaran tutor mencoba berbagai metode dan pendekatan untuk HD dan akhirnya sekarang sudah mau belajar di komunitas. Bahkan bisa dilihat kemajuan yang cukup baik untuk kontrol emosinya saat ini sehingga dapat bersosialisasi dengan teman lainnya.

AG yang memiliki basic penanaman disiplin yang kuat dari keluarganya namun ketika awal masuk di komunitas agak sulit di atur untuk belajar dan bertanggung jawab. Seiring berjalan waktu dengan kerja sama yang baik antara tutor dan orangtua maka penanaman disiplin tersebut dapat berkesinambungan terjadi di komunitas. Sekarang AG sudah mudah diajak untuk belajar dan mampu bertanggung jawab terhadap diri sendiri. Kemampuan membaca, menulis dan berhitungnya juga sudah menunjukkan kemajuan yang sangat baik sehingga mengalami peningkatan untuk nilai akademik. Begitu pula dengan penyesuaian budaya di Indonesia sudah memiliki pemahaman yang lebih baik karena terbiasa diajarkan oleh tutor dan teman-teman sebaya di komunitas.

ST yang termasuk kategori anak hyperactive dan terindikasi disleksia sehingga memiliki kesulitan penyesuaian belajar terutama untuk membaca, dan berhitung. Pihak HSKS sudah berupaya menyarankan kepada orangtua untuk memeriksakan ST ke pihak medis namun sampai saat ini belum dilakukan. Kesibukkan orangtua ST sedikit menjadi faktor penghambat untuk menerapkan pendidikan karakter yang berkesinambungan antara di komunitas dan di rumah sehingga berdampak pada kemajuan akademik dan perubahan perilaku yang terlihat lebih lambat dibandingkan anakanak lainnya.

Hasil dari implementasi pendidikan karakter berdasarkan penelitian yang sudah dilakukan memang memiliki pengaruh terhadap perkembangan kognitif. Hal ini bisa dilihat dari peningkatan hasil belajar dari ketiga homeschooler yang menjadi fokus penelitian. Hasil tersebut tidak mengharuskan pada peningkatan hasil belajar secara nume- 
rik namun kepada perkembangan yang ditunjukkan homeschooler dalam kemampuan membaca, menulis dan berhitung.

Perkembangan kognitif bagi homeschooler lebih difokuskan pada anak normal yang tidak memiliki masalah baik pada IQ dan EQ sehingga hasil belajarnya menjadi lebih baik setelah didukung dengan terbentuknya karakter yang baik. Seperti anak yang sebelumnya tidak bisa mandiri dan bertanggung jawab setelah memiliki nilai tersebut maka secara tidak langsung berdampak pada kesadarannya untuk belajar sehingga memiliki prestasi yang lebih baik.

Bagi anak-anak yang slower atau memiliki IQ di bawah rata-rata, sudah dilakukan berbagai upaya dalam proses pembelajaran namun kemampuan intelektualnya tidak bisa meningkat dengan baik maka pihak HSKS akan memfokuskan pada kematangan karakter. Potensi yang dimiliki anak dikembangkan secara optimal dengan menanamkan nilai-nilai kreativitas, mandiri, dan bertanggung jawab sehingga menjadi bekal dalam kehidupan di masa mendatangnya.

Homeschooling tidak seperti sekolah formal lainnya yang secara kaku hanya mementingkan perkembangan kognitif anak tanpa melihat aspek lainnya. Bagi mereka yang tidak puas dengan konsep pendidikan formal yang tidak bisa melayani kebutuhan anak sesuai karakteristiknya maka homeschooling menjadi alternatif untuk mengembangkan potensi anak yang berkebutuhan.

Homeschooling dengan karakteristik yang fleksibel mampu menggunakan semua metode dan pendekatan sesuai kebutuhan anak serta penanganan secara personal sehingga semua anak mendapatkan perhatian dan kebutuhannya terpenuhi dengan tepat. Oleh karena itu, banyak anak yang menunjukkan perubahan baik perkembangan akademik maupun perubahan perilaku yang lebih baik dibandingkan pertama kali datang ke HSKS dangan kondisi saat ini. Hal selanjutnya yang perlu dilakukan adalah menjaga kesinambungan proses pendidikan karakter yang diterapkan di HSKS, keluarga dan masyarakat untuk menjaga pemilihan nilai dan perilaku yang baik sehingga menetap dalam kehidupan sehari-harinya.

\section{SIMPULAN DAN SARAN}

\section{Simpulan}

Implementasi pendidikan karakter di HSKS Yogyakarta sudah berjalan melalui pembentukan karakter terpadu dengan pembelajaran pada mata pelajaran, manajemen sekolah, dan kegiatan pendukung maupun ekstrakurikuler.

Nilai-nilai yang ditanamkan kepada homeschooler di HSKS Yogyakarta mengacu kepada hasil finger print scan yaitu tanggung jawab, rasa hormat, keadilan, keberanian, jujur, disiplin, peduli, ketekunan, dan kemandirian.

Faktor pendukung yaitu pendekatan secara personal, dan faktor penghambat yaitu latar belakang keluarga yang sering memanjakan anak.

Hasil implementasi pendidikan karakter di HSKS yaitu perkembangan akademik yang meliputi peningkatan nilai akademik dan perubahan perilaku homeschooler. Perkembangan kognitif tidak menjadi tujuan utama bagi beberapa homeschooler yang memiliki keterbatasan IQ.

\section{Saran}

Peranan berbagai pihak khususnya orangtua dalam mewujudkan pendidikan karakter yang berkesinambungan.

Pemilihan nilai, kegiatan dan metode yang tepat sesuai dengan kondisi dan kebutuhan anak.

Hasil finger print scan dapat menjadi rujukan untuk pengembangan karakter anak dan divalidasi dengan hasil pengamatan.

\section{DAFTAR PUSTAKA}

Benninga, J.S., Berkowitz, M.W., Kuehn, Pyllis., et al. (2003). The relationship of character education implementation and academic achievement in elementary schools. Journal of Research in Character Education, 1, 19-32.

Dewantara, Ki Hadjar. (1977). Karya Ki Hadjar Dewantara: Bagian pertama: 
pendidikan. Yogyakarta: Majelis Luhur Persatuan Taman Siswa.

Kembara, Maulia D. (2007). Panduan lengkap homeschooling. Bandung: Progressio.

Kirschenbaum, H. (1995). 100 ways to enhance value and morality in schools and youth settings. Boston: Allyn and Bacon.

Lickona, T. (1991). Educating for character, how our schools can teach respect. Respect and responsibility. New York: Bantam Books.

(1993). The return of character education [versi elektronik]. Educational Leadership Journal, 51, 611.

(2004). Character matters: how to help our children develop and good judgment, integrity, and other essential virtues. New York: Simon \& Schuster Inc.

Linsenbach, S. (2010). The everything homeschooling book: all you need to create the best curriculum and learning environment for your child ( $2 r d$ ed). Adams Media: Avon.

Megawangi, Ratna. (2009). Pendidikan karakter solusi yang tepat untuk membangun bangsa. Bogor: Indonesia Heritage Foundation.

Mulyadi, Seto. (2007). Homeschooling keluarga kak seto: mudah, murah, meriah, dan direstui pemerintah. Bandung: Kaifa.

Saputro, Abe. (2007). Rumahku sekolahku: panduan bagi orangtua untuk menciptakan homeschooling. Yogyakarta: Graha Pustaka.

Yin, R.K. (2008). Studi kasus desain $\mathcal{E}$ metodologi. Jakarta: Raja Grafindo Persada.

Zuchdi, Darmiyati dkk. (2012). Model pendidikan karakter terintegrasi dalam pembelajaran dan pengembangan kultur sekolah. Yogyakarta: UNY Press. 